\title{
Coordinate-Sensitive Receiver
}

\author{
D.D. Alijanov", Bakhranov Sh.K. \\ Andijan Machine Building Institute, Uzbekistan.
}

*Corresponding Author: D.D. Alijanov, Andijan Machine Building Institute, Uzbekistan.

\begin{abstract}
This article presents the results of studies of the effect of abnormally high photoelectric voltages $(A P V)$ in semiconductor film systems, which can be considered as current generators under the influence of incident radiation. The technique is described for the first time and the results of experimental studies of the possibility of obtaining an effective coordinate-sensitive optical radiation detector (ORD) from semiconductor compounds in the form of a step-like APV film are presented. Based on such a photo-generator, a twodimensional coordinate-sensitive autonomous object can be developed, the output signal of which contains information about the object and the magnitude of the radiating object along the $X$ and $Y$ axes.
\end{abstract}

Keywords: Coordinate-sensitive, APV film, semiconductor, photovoltage, optical radiation detector, twodimensional coordinate-sensitive, VUP-5k.

\section{INTRODUCTION}

The technology for producing APV films is based on thermal evaporation of semiconductor materials in a vacuum of $10^{-3}-10^{-5} \mathrm{~mm} \mathrm{Hg}$. In [1-12], APV films from various semiconductor materials with a wide and narrow band gap - $\mathrm{CdTe}, \mathrm{Si}, \mathrm{Ge}, \mathrm{GaAs}, \mathrm{GaP}, \mathrm{Se}, \mathrm{PbS}$ chalcogenide alloys - were obtained using the vacuum evaporation method. However, films produced by this method have a low generated voltage. The technological regime for the production of APV films depends on a large number of parameters, such as the temperature of the substrate and the evaporator, the deposition angle, wall thickness, the composition and pressure of the residual gases in the vacuum chamber, the conditions for the thermal treatment of the films after deposition, etc. It is most efficient to fabricate APV films based on a cadmium telluride compound, including applying the starting material to one side of the substrate by thermal evaporation in vacuum, where cadmium telluride is used as the starting material, a reflective layer of silver is applied to the opposite side of the substrate at a temperature of 250 $300^{\circ} \mathrm{C}$ and pressure $5 \cdot 10^{-4}-5 \cdot 10^{-3} \mathrm{mmHg}\left(6,65 \cdot 10^{-2}-6,65 \cdot 10^{-1} \mathrm{~Pa}\right)$, the substrate is placed at an angle of $45^{\circ}$ to the direction of the molecular beam to create a surface angular anisotropy, leading to the appearance of anomalous photo voltage. Part of the incident light flux passing through the starting material and the glass substrate falls on a silver reflecting layer and, being reflected, falls on the back side of the cadmium telluride layer, as a result of which additional absorption of light occurs and thereby the generated photovoltage increases by some APV values [4 -7].

\section{Coordinate Sensitive Photo Receivers}

Depending on the functional capabilities, ORDs are subdivided into amplitude (integral) ones, which respond only to the average illumination value of their photosensitive surface, and coordinatesensitive (informational), which respond to the spatial distribution of the optical signal. Coordinatesensitive ORDs, in turn, are divided into selectively transformative, position-sensitive, and twodimensional coordinate-sensitive

The matrix APV receiver [8] transforming the distributed radiation flux (optical image) into an electric potential relief is created on a glass metal plate with discrete anisotropic conductivity, consisting of a glass base 1 and thin insidious wires piercing it 2 (Fig. 1). A thin layer of platinum 3 is applied to one of the sides of such a glass-metal plate by cathodic sputtering, after which holes 4 are created using an insidious etchant.

A photosensitive semiconductor film is generated on the surface of a plate thus prepared by thermal evaporation in vacuum, which generates APV under illumination. Spraying is performed at an angle 
to the normal ( 5 is the direction of the molecular beam), as a result of which a discrete photovoltaic element 6 is formed on the side surface of each well in the form of an APV film in contact with one end with an inset fiber (output of an elementary photo cell) and with the other platinum an electrode on the surface of the plate. The system of such micro photoelectric elements forms a photo detector matrix, which is an autonomous sensor of multi-element optical information

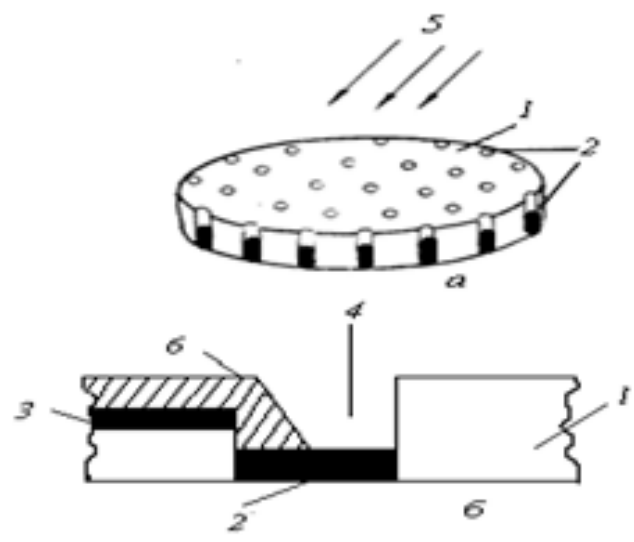

Fig1. The structure of the matrix APV-optical image converter into an electric potential relief: a - appearance, $b$ - section.

When an optical image is applied to the active surface of a glass-metal plate, the described matrix sensor creates at the ends of the insidious fibers extending onto the second surface an electric potential relief corresponding to the intensity distribution in the incident light flux.

Unlike all known matrix photo detectors, the described structure works without external sources of electrical power. We also note that it is a photosensitive matrix with high spatial resolution, the manufacture of which does not require complex and precision masking technology, used for applying micro photoelectric elements and combining them with current collector electrodes in solid-state matrices of known types.

Position-sensitive ORDs allow you to select information only on the coordinate of one point radiation source, which significantly exceeds the intensity of background illumination.

Based on the above technology, position-sensitive APV films were obtained and a position-sensitive stand-alone optical radiation detector KCHP - 1M was made, which consists of a glass substrate, a photosensitive APV film from semiconductor material, and metal contacts $[9,10]$.

However, KChP $-1 \mathrm{M}$ has a low sensitivity to the coordinates of optical radiation due to the inhomogeneous structure of the obtained APV layer.

In [11-12], a procedure was described and the results of an experimental study of obtaining an effective position-sensitive ORD from semiconductor compounds in the form of a step-like APV film with a gradual increase in the thickness of steps starting from $1 \mu \mathrm{m}$ are presented.

To obtain films of various thicknesses, the VUP-5k vacuum unit was used. In the working chamber, the vacuum reached about $10-4 \ldots 10-5 \mathrm{~mm} \mathrm{hg}$. st. substrate temperature $310 \ldots 480^{\circ} \mathrm{C}$, the substrate was placed at an angle of $45^{\circ}$ to the direction of the molecular beam.

As substrates, glass $2 \mathrm{~mm}$ thick was used. The prepared substrates were placed in a special holder, and a mask of insulating material (getinax) was installed on the surface of the substrate. A micro electric motor (2 rpm) was installed in the working chamber to open or close the surface of the substrate. Opening the surface of the substrate is carried out by an electric motor using a light heatresistant cord associated with a mask. When the engine rotates, the surface of the substrate gradually opens. Films obtained on a substrate with a size of $220 \mathrm{~mm}$ are stepwise. The thickness of each step was determined using an MII-4 interference microscope.

Figure 2 shows an image of an abnormally photo-stressed film. The incident light flux $\Phi 0$ generates an APV. When moving the position of monochromatic radiation from a step with a film thickness of $1 \mu \mathrm{m}$ to a step with a film thickness of $2.0 \mu \mathrm{m}$, the generated photo voltage VAPV decreases proportionally. 
After analyzing the graphs of the dependence of VAPV on thickness, we can assume that the APV effect in cadmium telluride films is related to the summation of the stresses of the pn junctions formed at the boundary of the hexagonal and cubic phases. Numerous experiments [1-7] show that for cadmium telluride films, the effective thickness of the sensitive layer is $1 \mu \mathrm{m}$. The dependences of VAPV on the film thickness were studied (Fig. 3).

In the thermally treated films studied by us, the photovoltage first increased (up to $1 \mu \mathrm{m}$ thickness), and then decreased with increasing thickness. Monochromatic illumination in all measurements was maintained constant $\mathrm{I}=104$ lux.

Method 1. A photosensitive layer is applied by thermal evaporation of crystalline cadmium telluride at a temperature of $420^{\circ} \mathrm{C}$ in a vacuum of $10-5 \mathrm{~mm} \mathrm{hg}$. st. on a glass substrate located at an angle of $45^{\circ}$ to the direction of the molecular beam, with the mask initially closed. The mask opens stepwise, providing a stepwise change in film thickness. The thickness of the steps is: 0.8 microns; 1.3 microns; 1.5 microns; 1.8 microns. APV values on the steps: $65 \mathrm{~V} ; 32 \mathrm{~V} ; 26 \mathrm{~V} ; 8 \mathrm{~V}$, respectively, at I =104 lux.

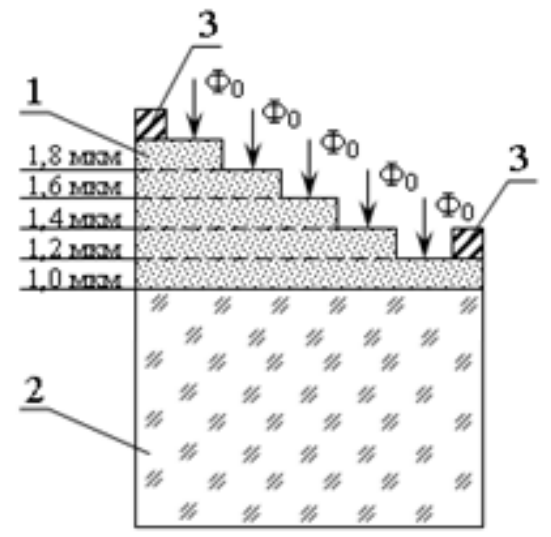

Fig2. Coordinate-sensitive APV film

1 - step-like photosensitive layer of crystalline cadmium telluride;

2 - glass substrate

3 - metal contacts,

$\Phi_{0}$ - incident incident monochromatic radiation flux.

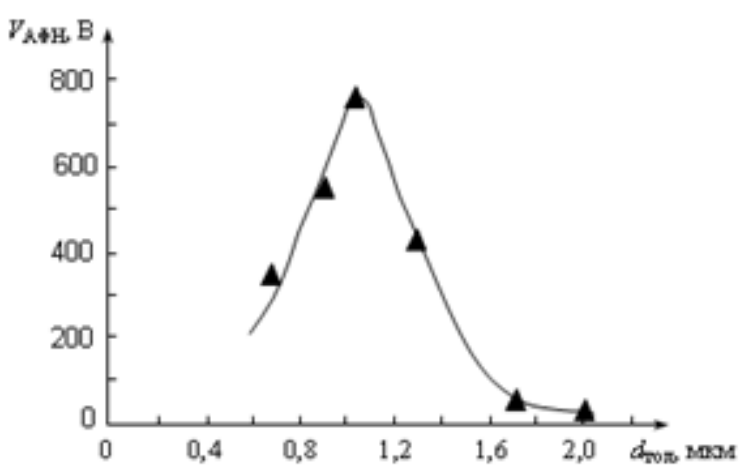

Fig3. The dependence of $V_{A P V}$ on the film thickness

Method 2. The photosensitive layer is applied by thermal evaporation of crystalline cadmium telluride at a temperature of $470^{\circ} \mathrm{C}$ in a vacuum of $10^{-5} \mathrm{~mm} \mathrm{hg}$. st. on a glass substrate located at an angle of $45^{\circ}$ to the direction of the molecular beam, with the mask initially closed. The mask opens stepwise, providing a stepwise change in film thickness. The thickness of the steps is: 0.9 microns; 1.4 microns; 1.6 microns; 1.8 microns; 2.0 microns. APV values on the steps: $55 \mathrm{~V} ; 38 \mathrm{~V} ; 33 \mathrm{~V} ; 26 \mathrm{~V} ; 12 \mathrm{~V}$, respectively, at $\mathrm{I}=10^{4}$ lux.

Method 3. The photosensitive layer is applied by thermal evaporation of crystalline cadmium telluride at a temperature of $480^{\circ} \mathrm{C}$ in a vacuum of $10^{-4} \mathrm{~mm} \mathrm{hg}$. st. on a glass substrate located at an angle of 
$45^{\circ}$ to the direction of the molecular beam, with the mask initially closed. The mask opens stepwise, providing a stepwise change in film thickness. The thickness of the steps is: 0.9 microns; $1.0 \mu \mathrm{m} ; 1.3$ microns; 1.8 microns. APV values on the steps: $86 \mathrm{~V} ; 110 \mathrm{~V} 38 \mathrm{~V} ; 26 \mathrm{~V}$, respectively, at I $=10^{4}$ lux.

Method 4. A photosensitive layer is applied by thermal evaporation of crystalline cadmium telluride at a temperature of $480^{\circ} \mathrm{C}$ in a vacuum of $10^{-4} \mathrm{~mm} \mathrm{hg}$. st on a glass substrate located at an angle of $45^{\circ}$ to the direction of the molecular beam, with the mask initially closed. The mask opens stepwise, providing a stepwise change in film thickness. The thickness of the steps is: $1.0 \mu \mathrm{m} ; 1.2$ microns; 1.4 microns; 1.6 microns; 1.8 microns. AFS values on the steps: $150 \mathrm{~V} ; 96 \mathrm{~V} ; 85 \mathrm{~V} ; 43 \mathrm{~V} ; 22 \mathrm{~V}$, respectively, at $\mathrm{I}=10^{4}$ lux.

Based on the position-sensitive photo-generator described above, it is possible to develop a positionsensitive autonomous receiver of optical radiation, the output signal of which will contain information about the direction and magnitude of the displacement of the emitting object, which was done.

The main parameters of a position-sensitive optical radiation detector based on an AFD film from CdTe: sensitivity $2 . .5 \mathrm{~V} / \mathrm{mm}$ at 10 lx illumination; internal resistance $1012 \ldots 1014 \mathrm{Ohm}$; time constant $0.8 \ldots 1.0 \mathrm{~s}$; radiation spectrum $0.5 \ldots 0.83$ microns; sensitive area $2 \times 15 \mathrm{~mm}$. Dimensions of the receiver $2 \times 2 \times 21 \mathrm{~mm}$, weight not more than $3.0 \mathrm{~g}$.

Two-dimensional coordinate-sensitive ORD is one of the most universal, since it allows you to convert all information about the spatial distribution of the intensity of the optical signal into an electrical signal. Most two-dimensional coordinate-sensitive ORDs use the principle of a chargecoupled device (CCD). In [13], a two-dimensional coordinate-sensitive sensor was obtained for recording the parameters of optical radiation, consisting of a photodetector, for example, a CCD matrix, in front of which an optical element was installed, the transmittance of which varies depending on the location on the light diameter of the element. The disadvantage of these sensors is the complexity of the optical system, low sensitivity and the mandatory use of power.

Based on this, the task was posed of creating a two-dimensional coordinate-sensitive autonomous receiver of optical radiation of high sensitivity [14].

This goal is achieved by the fact that a two-dimensional coordinate-sensitive autonomous optical radiation receiver obtained from semiconductor compounds in the form of a two-dimensional (along the $\mathrm{X}$ and $\mathrm{Y}$ coordinates) step-like APV film with a gradual increase in the thickness of the steps along the $\mathrm{X}$ axis, with continued increase at each next step along $\mathrm{Y}$ axis or vice versa.

To obtain films of various thicknesses, the VUP-5k vacuum unit is used. In the working chamber, the vacuum reaches about $10^{-4} \ldots 10^{-5} \mathrm{~mm} \mathrm{hg}$. st, the temperature of the substrate $310 \ldots 480^{\circ} \mathrm{C}$, the substrate is placed at an angle of $45^{\circ}$ to the direction of the molecular beam. As substrates, glass $2 \mathrm{~mm}$ thick is used. Prepared substrates are placed in a special holder and a double-wing mask made of insulating material (getinax) is installed on the surface of the substrate. Identical microelectric motors $(2 \mathrm{rpm})$ are installed in the working chamber to open or close the surface of the substrate by mutually perpendicular movement of the respective shutters. The surface of the substrate is opened by electric motors with the help of light heat-resistant cables connected with curtains. The rotation of the engines gradually opens the surface of the substrate. Films obtained on a substrate with a size of $21 \times 21 \mathrm{~mm}^{2}$ are two-dimensionally stepwise along the $\mathrm{X}$ and $\mathrm{Y}$ axes. The thickness of each step is determined using an MII-4 interference.

Figure 4 shows the images of the APV film. The incident light flux $\Phi_{0}$ generates the photo voltage of the APV. When the position of monochromatic radiation is moved from a step with a film thickness of $1 \mu \mathrm{m}$ to a step with a film thickness of $2.6 \mu \mathrm{m}$, the generated photovoltage $V_{\mathrm{APV}}$ decreases proportionally.

In the studied thermally treated films, the photovoltage initially increased (to a thickness of $1 \mu \mathrm{m}$ ), and then decreased with a subsequent increase in thickness. Monochromatic illumination in all measurements was maintained constant $\mathrm{I}=10^{4} \mathrm{~lx}$.

Method 1. The photosensitive layer is applied by thermal evaporation of crystalline cadmium telluride at a temperature of $420^{\circ} \mathrm{C}$ in a vacuum of $10^{-5} \mathrm{~mm} \mathrm{RT}$. Art. on a glass substrate located at an angle of $45^{\circ}$ to the direction of the molecular beam with the initial closed mask blinds. First, the Y curtain opens one step at a subsequent step-by-step opening of the second curtain along the $\mathrm{X}$ axis. After the 
shutter is completely opened on the $\mathrm{X}$ axis, it returns to its original position, and the $\mathrm{y}$ curtain opens another step, and so on until the entire mask is fully opened. The thickness of the steps with a matrix size of $3 \times 3$ are: $0.8 \mu \mathrm{m} ; 1.0 \mu \mathrm{m} ; 1.2$ microns; 1.3 microns; 1.5 microns; 1.8 microns; 2.0 microns; 2.3 microns; 2.6 microns. APV values on the steps: $45 \mathrm{~V} ; 60 \mathrm{~V} ; 51 \mathrm{~V} ; 45 \mathrm{~V} ; 34 \mathrm{~V} ; 31 \mathrm{~V} ; 17 \mathrm{~V} ; 6 \mathrm{~V} ; 2 \mathrm{~V}$, respectively, at $\mathrm{I}=10^{4}$ lux.

Method 2. The photosensitive layer is applied by thermal evaporation of crystalline cadmium telluride at a temperature of $420^{\circ} \mathrm{C}$ in a vacuum of $10^{-5} \mathrm{~mm} \mathrm{hg}$. st. on a glass substrate located at an angle of $45^{\circ}$ to the direction of the molecular beam with the initial closed mask blinds. First, the Y curtain opens one step at a subsequent step-by-step opening of the second curtain along the $\mathrm{X}$ axis. After the shutter is completely opened on the $\mathrm{X}$ axis, it returns to its original position, and the y curtain opens another step, and so on until the entire mask is fully opened. The thickness of the steps with a matrix size of $3 \times 3$ are: $0.9 \mu \mathrm{m} ; 1.2$ microns; 1.4 microns; 1.6 microns; 1.8 microns; 1.9 microns; 2.1 microns; 2.3 microns; 2.5 microns. APV values on the steps: $55 \mathrm{~V} ; 48 \mathrm{~V} ; 40 \mathrm{~V} ; 38 \mathrm{~V} ; 31 \mathrm{~V} ; 27 \mathrm{~V} ; 18 \mathrm{~V} ; 9 \mathrm{~V} ; 3$ $\mathrm{V}$, respectively, at $\mathrm{I}=10^{4}$ lux.
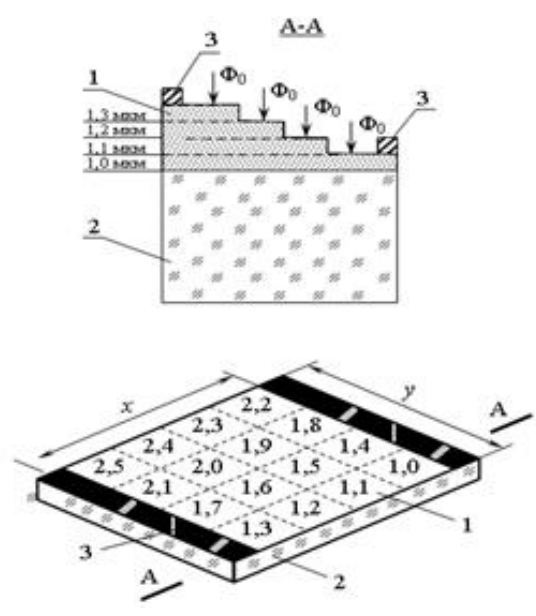

Fig4. Two-dimensional step-like photosensitive APV film:1 - two-dimensional step-like photosensitive layer of crystalline cadmium telluride; 2 - glass substrate; 3 - metal contacts; $\Phi_{0}$ - incident monochromatic radiation flux.

Method 3. The photosensitive layer is applied by thermal evaporation of crystalline cadmium telluride at a temperature of $420^{\circ} \mathrm{C}$ in a vacuum of $10^{-5} \mathrm{~mm}$ hg.st. on a glass substrate located at an angle of $45^{\circ}$ to the direction of the molecular beam with the initial open curtains of the mask. First, the $\mathrm{Y}$ axis shutter closes one step at a subsequent step-by-step closing of the second $X$ axis shutter. After the shutter is completely closed on the $\mathrm{X}$ axis, it returns to its original position, and the $\mathrm{Y}$ axis shutter closes another step, and so on until the entire mask is completely closed. The thickness of the steps with a matrix size of $3 \times 3$ are: $1.0 \mu \mathrm{m} ; 1.3$ microns; 1.4 microns; 1.5 microns; 1.7 microns; 1.8 microns; 2.0 microns; 2.1 microns; 2.3 microns. APV values on the steps: $68 \mathrm{~V} ; 52 \mathrm{~V} ; 44 \mathrm{~V} ; 41 \mathrm{~V} ; 34$ $\mathrm{V} ; 27 \mathrm{~V} ; 23 \mathrm{~V} ; 15 \mathrm{~V} ; 8 \mathrm{~V}$, respectively, at $\mathrm{I}=10^{4}$ lux.

Method 4. The photosensitive layer is applied by thermal evaporation of crystalline cadmium telluride at a temperature of $420^{\circ} \mathrm{C}$ in a vacuum of $10^{-5} \mathrm{~mm}$ hg.st. on a glass substrate located at an angle of $45^{\circ}$ to the direction of the molecular beam with the initial open curtains of the mask. First, the $\mathrm{Y}$ axis shutter closes one step at a subsequent step-by-step closing of the second $\mathrm{X}$ axis shutter. After the shutter is completely closed on the $\mathrm{X}$ axis, it returns to its original position, and the $\mathrm{Y}$ axis shutter closes another step, and so on until the entire mask is completely closed. The thickness of the steps with a matrix size of $3 \times 3$ are: $1.0 \mu \mathrm{m} ; 1.1 \mu \mathrm{m} ; 1.3$ microns; 1.4 microns; 1.6 microns; 1.7 microns; 1.9 microns; 2.2 microns; 2.5 microns. APV values on the steps: $78 \mathrm{~V} ; 58 \mathrm{~V} ; 45 \mathrm{~V} ; 41 \mathrm{~V} ; 32 \mathrm{~V} ; 26 \mathrm{~V} ; 14$ $\mathrm{V} ; 8 \mathrm{~V} ; 5 \mathrm{~V}$, respectively, at $\mathrm{I}=10^{4}$ lux.

\section{CONCLUSION}

Based on such a generator, a two-dimensional coordinate-sensitive autonomous ORD can be developed, the output signal of which contains information about the direction and magnitude of the displacement of the radiating object along the $\mathrm{X}$ and $\mathrm{Y}$ axes. 
Based on the APV film obtained by the method of obtaining a two-dimensional coordinate-sensitive photo-generator, a two-dimensional coordinate-sensitive autonomous ORD is produced, designed to determine the coordinates of the light source.

\section{REFERENCES}

[1] Raximov N.R. Ser'yoznov A.N. APV-plenki i ix primenenie / monografiya. - Novosibirsk: SibNIA, 2005. - 64 s.

[2] Raximov N.R., Mamadalieva L.K. // Izv. vuzov. Priborostroenie. 2004. T 47. №8. S. 53-56.

[3] Alizhanov D.D. Osobennosti poluchenija fotochuvstvitel'nyh plenok s anomal'nym fotonaprjazheniem // Avtomatika i programmnaja inzhenerija. -2013. -№ 3 (5). -S. 81-84

[4] Rahimov N.R., Alizhanov D.D., ZHmud V.A. Plemenos D., Reva I.L. Perspektivy primenenija AFNpriemnika dlja razrabotki optojelektronnoj informacionno-izmeritel'noj sistemy // Nauchnyj vestnik NGTU. - 2014. - S. 181-188

[5] Zhmud V.A., Rakhimov N.R., Alijanov D.D. The Independent Receiver of Optical Radiation on Basis of APV of Structures for Automatic Optoelectronic Devices / Proceeding CIMHAR-2011. P. $27-30$.

[6] Alizhanov D.D., Rahimov N.R., ZHmud' V.A. / Razrabotka optojelektronnyh datchikov na osnove AFNplenok iz poluprovodnikovyh soedinenij // Sbornik nauchnyh trudov NGTU. - 2012. - №2 (68). - S. 37-42.

[7] Rahimov N.R., Alizhanov D.D. Matematicheskaja model' AFN priemnika // Muhammad al-Horazmij avlodlari №2(4) 2018.

[8] Mastov E.M. Issledovanie anomal'nogo bol'shogo fotomagnitnogo effekta $\mathrm{v}$ plenkax tellurida kadmiya: dis. kand. fiz.-mat. nauk. - Tashkent, 1972. - 125 s.

[9] Rahimov N.R., Dzhurakhalov A.A. Investigation of APV-CdTe-films and development of optoelectronic devices on their basis / The European material research conference EMRS 2002 Spring meeting. Strasbourg-France, 2002. - P. 242.

[10] Rahimov N.R., Alizhanov D.D Osobennosti poluchenija koordinatno-chuvstvitel'nogo priemnika opticheskogo izluchenija na osnove poluprovodnikovyh plenok s anomal'nym fotonaprjazheniem // Avtomatika i programmnaja inzhenerija. -2012. -№ 2 (2). -S. 41-46.

[11] Raximov N.R, A.N. Ser'yoznov. Koordinatno-chuvstvitel'niy avtonomniy priemnik opticheskogo izlucheniya / Patent RF №2246779, BI. 2005. №5.

[12] Raximov N.R, Ser'yoznov A.N. Koordinatno-chuvstvitel'niy priemnik opticheskogo izlucheniya na osnove plenok s anomal'nim fotonapryajeniem / PTE, 2005. № 4. - S. 125-126.

[13] Zayavka № 19714820 Germaniya, MPK6 G 01 J 1/22, B 64 G 1/36. Optischer positionsauflösender Sensor. Opub. 15.10.98.

[14] Raximov N.R., Ser'yoznov A.N., Petrov P.M.. Dvumerniy koordinatno-chuvstvitel'niy priemnik opticheskogo izlucheniya / Pol. reshenie po zayavke 2005 113383/28 k vidache patenta RF.

Citation: D.D. Alijanov \& Bakhranov Sh.K, (2019). " Coordinate-Sensitive Receiver". International Journal of Research Studies in Electrical and Electronics Engineering (IJRSEEE), 5(4), pp 17-22. DOI: http://dx.doi. org/10.20431/2454-9436.0504004

Copyright: () 2019 Authors. This is an open-access article distributed under the terms of the Creative Commons Attribution License, which permits unrestricted use, distribution, and reproduction in any medium, provided the original author and source are credited. 